\title{
Reflections
}

\section{Who welcomes? The geographies of refugee aid as care work - commentary to Gill}

\author{
ELISA PASCUCCI
}

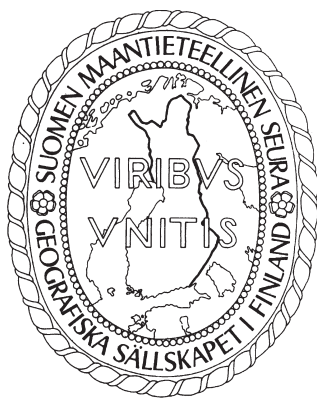

Pascucci, E. (2018) Who welcomes? The geographies of refugee aid as care work - commentary to Gill. Fennia 196(2) 236-238. https://doi. org/10.11143/fennia.76588

Drawing on my recent research with aid workers in Jordan and Lebanon, as well as on examples from Greece and Italy, in this commentary I propose the concept of care work as one of the possible ways to achieve a grounded critical understanding of welcome, one that goes beyond solidarity versus institutionalization, bureaucracy versus generosity and state versus civil society dichotomies. Framing the issue in such a way means asking three fundamental questions: not only, as Gill poignantly does, what is welcome, but also where is welcome actually located and, most importantly, who welcomes. These questions illuminate the many overlooked forms of affective and physical labour without which statecentred, institutional, and internationally organized aid and "welcome" would not be possible. The task, I contend, is to unearth the labour of care that the governance of migration and refuge requires, labour that is mostly feminized, racialized, and precarious. By illuminating the forms of care and interdependencies upon which the reproduction of our societies depends - in all its aspects, including border regimes - this perspective opens up an emancipatory pathway to the politicization of welcoming and aid to migrants and refugees, alternative to humanitarian discourses.

Keywords: refugees, welcome, care, labour, feminist geography

Elisa Pascucci, EuroStorie Centre of Excellence, University of Helsinki, Siltavuorenpenger 1 A, P.O. Box 9, 00014 Helsinki Finland. E-mail: Elisa. Pascucci@helsinki.fi

Nick Gill's (2018) commentary “The suppression of welcome", based on the keynote address given at the 2017 Annual Meeting of Finnish Geographers, in Turku, and published in Fennia earlier this year, focuses on the tension between bureaucratic, state-centred forms of welcome and the emotional and intimate character of grassroots and spontaneous solidarities towards migrants and refugees. The essay offers a number of extremely important insights that go into the direction of challenging Eurocentric and institutional humanitarian conceptions of welcoming refugees. Among other important points, Gill mentions the centrality of emotional labour in practices of welcome, and the emerging South-South geographies of hospitality, although he does not fully engage with these concepts. The author concludes by stressing the need for welcoming efforts to accommodate both organizational, institutional and systematic elements, and the emotionally lively, in-depth, intersubjective exchanges that characterize "welcome as experienced"- "a delicate balance", he writes, to be "struck at the local, national and international level" (Gill 2018, 94). 
Gill is right to see in Greece an important site for the struggle over welcome that characterizes contemporary migration and refugee politics. Indeed, the Greek landscape of abject containment through camps and militarized borders, resulting from the enforcement of the EU-Turkey deal on refugees of March 2016, is not only about controlling the movement of migrant bodies. It is also a way to channel and govern the outpour of local and transnational solidarities that had characterized the 2015 so-called "refugee crisis" in the Southern Balkans (Mitchell \& Sparke 2018, Pallister-Wilkins 2018). Yet the case of Greece, like those of other Southern European and Southern Mediterranean countries, also highlights the need for a more nuanced understanding of the relation between bureaucratic control and the affective, embodied, spontaneous and caring character of "alternative" forms of welcome. Drawing on my recent research with aid workers in Jordan and Lebanon (Pascucci 2018), as well as on examples from Greece and Italy, in this commentary I propose the notion of refugee welcome as care work as one of the possible ways to achieve such grounded critical understanding. Framing the issue in such a way means asking three fundamental questions: not only, as Gill (2018) poignantly does, what is welcome, but also where is welcome actually located and, most importantly, who welcomes. These questions illuminate the many overlooked forms of affective and physical labour without which state-centred, institutional, and internationally organized aid and "welcome" would not be possible. Rather than reproducing dichotomies such as solidarity versus institutionalization, bureaucracy versus generosity and state versus civil society, the task, I contend, is to unearth the labour of care that the governance of migration and refuge requires, labour that is mostly feminized, racialized, and precarious. By illuminating the forms of care and interdependencies upon which the reproduction of our societies depends - in all its aspects, including border regimes - this perspective opens up an emancipatory pathway to the politicization of welcoming and aid to migrants and refugees, alternative to humanitarian discourses.

Most of us are now familiar with the UNHCR statistics that show how the vast majority of Syrian refugees - to mention but one of the recent mass displacement crises, and the one that, having directly affected Europe, received the most attention by international media - are displaced within the Middle East, particularly in Syria's neighbouring countries like Turkey and Lebanon (UNHCR 2017). However, not everyone is aware of existing research estimates according to which up to $90 \%$ of the workforce employed today in the humanitarian sector in the Global South, including refugee aid, is constituted by locally-recruitedstaff, whose labour is regulated by the often inadequate insurance and contractual standards enforceable in many post-conflict and developing countries (Egeland et al. 2011). These two facts powerfully question common views of aid and welcome as following a NorthSouth, affluent-to-poor, and sedentary-to-mobile (many aid agencies employ staff who have a migrant background themselves) trajectory, and demand that we pay more attention to where welcome actually takes place - to what are its locations, mobilities and directions.

The answer to the question who welcomes is often a precariously employed care and social worker from the Global South or Southern Europe. During my fieldwork in Lesvos and Athens, in 2016, few months after the EU-Turkey agreement had come into force, it was not uncommon for the staff of local and international aid organizations to comprise Greek graduates to whom - after difficult experiences of protracted unemployment - the so-called "refugee crisis" had offered the first, if precarious, job opportunity. The experience of young Jordanian and Lebanese workers employed by UN offices and international non-governmental organizations (NGOS) in the assistance to Syrian refugees is marked by similar trajectories. These workers often highlight the racialized hierarchies that exist within aid organizations, and which operate through a division of labour that puts the burden of emotionally and physically draining tasks disproportionately on non-white, non-expatriate staff (Pascucci 2018; see also Fluri \& Lehr 2017 on the case of local aid workers in Afghanistan). As Gill (2018) also remarks, welcoming and assisting refugees "on the ground", be it in camps, reception centres, or legal assistance offices, necessitates skills, particularly languages and the manual and interpersonal skills that care work demands. Yet state institutions and non-governmental aid organizations rarely acknowledge these skills, and the labour of the lower-rank aid workers that hold them, as valuable. Considering refugee assistance as care work exposes the gendered and racialized labour relations that obscure such practical and embodied knowledges. 
How can geography assist us in such endeavour, and why is it relevant? Feminist postcolonial geographers have long advocated a "dislocation" of care studies beyond the Global North that would allow us to assess what "the actually-existing global variations of care imply for our ethico-political theorizing" (Raghuram 2016, 517). When not entirely "suppressed", to borrow the term Gill (2018) uses in his title, by racist hostility and violent border enforcement, institutional and state-centred welcome often presumes the inherent fragility of the welcomed other and the effortful generosity of the powerful "host" (see Raghuram et al. 2009). Instead, it is imperative that we shed light on the actuallyexisting "labour of welcoming" performed by low-paid, precarious care workers, as part of a broader critical geographical project that focuses on "potential connections and disconnections between responsibility, care and power, at a variety of scales" (Raghuram et al. 2009, 10). Exposing the interrelated geometries of care and labour that are concealed by global borders and global inequalities is an essential precondition for economic, social and political change (Folbre 2014; Pascucci 2018). The experience of the Italian Assemblea dei Lavoratori dell'Accoglienza (A.L.A. - The Assembly of Welcome Workers), an association of - mostly precarious - care and social workers in the migration and refugee reception sector, active in particular in Rome and Bologna, has shown how the demand for better working conditions in the private and public care sector can become an essential ally to struggles for migrant rights. ${ }^{1}$ Contesting the precarization of their own labour conditions, these workers have exposed the various attempts at privatization and securitization of asylum seekers reception that have accompanied the implementation of the so-called "security laws" (decreto or pacchetto sicurezza) approved by recent governments in Italy. Their intersectional, interdependent "alliance of the exploited and the precarious", in the Assemblea's own words, is a testament of the political potential of looking at welcome as care work.

\section{Notes}

1 <http://www.sialcobas.it/2016/02/1-marzo-lappello-dei-lavoratori-dellaccoglienza-di-roma/>

\section{References}

Egeland, J., Harmer, A. \& Stoddard, A. (2011) To Stay and Deliver: Good Practice for Humanitarians in Complex Security Environments. Policy Development and Studies Bureau, UN Office for the Coordination of Humanitarian Affairs (UNOCHA), New York. <https://www. humanitarianoutcomes. org/publications/stay-and-deliver-good-practice-humanitarians-complex-security-environments $>$ 19.11.2018.

Fluri, J. \& Lehr, R. (2017) The Carpetbaggers of Kabul and Other American-Afghan Entanglements: Intimate Development, Geopolitics and the Currency of Gender and Grief. University of Georgia Press, Athens.

Folbre, N. (2014) Who Cares? A Feminist Critique of the Care Economy. Rosa Luxemburg Stiftung, New York. <http://www.rosalux-nyc.org/wp-content/files_mf/folbre_whocares.pdf> 19.11.2018.

Gill, N. (2018) The suppression of welcome. Fennia 196(1) 88-98. https://dx.doi.org/10.11143/ fennia.70040

Mitchell, K. \& Sparke, M. (2018) Hotspot geopolitics versus geosocial solidarity: contending constructions of safe space for migrants in Europe. Environment and Planning D: Society and Space. https://doi.org/10.1177/0263775818793647

Pallister-Wilkins, P. (2018) Hotspots and the geographies of humanitarianism. Environment and Planning D: Society and Space. https://doi.org/10.1177/0263775818754884

Pascucci, E. (2018) The local labour building the international community: precarious work within humanitarian spaces. Environment and Planning A: Economy and Space. https://doi. org/10.1177/0308518X18803366

Raghuram, P. (2016) Locating care ethics beyond the global North. ACME: An International Journal for Critical Geographies 15(3) 511-533.

Raghuram, P., Madge, C. \& Noxolo, P. (2009) Rethinking responsibility and care for a postcolonial world. Geoforum 40 5-13. https://doi.org/10.1016/j.geoforum.2008.07.007

UNHCR (2017) Syria Regional Refugee Response: Inter-agency Information Sharing Portal. <http:// data.unhcr.org/syrianrefugees/regional.php> 19.11.2018. 